\title{
The Effect of Corporate Governance Mechanism, Liquidity and Company Size on Tax Avoidance
}

Elgina Sari Novita*, Yudhi Herliansyah

Universitas Mercu Buana Jakarta

DOI: $10.36348 /$ SJEF.2019.v03i09.001

| Received: 28.08.2019 | Accepted: 05.09.2019 | Published: 11.09.2019

*Corresponding author: Elgina Sari Novita

\section{Abstract}

This research is to examine the effect of corporate governance mechanisms, liquidity and firm size on tax avoidance. The population this research are all logistics and transportation service companies on the Indonesia Stock Exchange in the period 2012-2017. The selection samples using purposive sampling method with non-probability sampling techniques so that the number of samples is determined by 18 logistics and transportation service companies listed on the Indonesia Stock Exchange for the period 2012-2017. This research data analysis method used multiple linear regression models with the help of SPSS version 20.00. The results of this research prove that independent commissioners, managerial ownership, size of directors, liquidity, and company size partially have no significant effect on tax avoidance. Whereas institutional ownership and audit committees have a significant effect on tax avoidance. The results of the study simultaneously proved that independent commissioners, managerial ownership, board size, liquidity, institutional ownership, audit committee, and company size had a significant effect on tax avoidance.

Keywords: Independent Commissioners, Managerial Ownership, Directors' Size, Liquidity, Institutional Ownership, Audit Committee, Company Size, and Tax Avoidance.

Copyright @ 2019: This is an open-access article distributed under the terms of the Creative Commons Attribution license which permits unrestricted use, distribution, and reproduction in any medium for non-commercial use (NonCommercial, or CC-BY-NC) provided the original author and source are credited.

\section{INTRODUCTION}

Significant industrial growth caused the Indonesian Government in 2008 to carry out tax reforms which resulted in the revision of Law No. 36 of 2008. The result of the revision is the provision of incentives to the Corporate WP, namely the reduction in tax rates. Taxes in companies get sufficient attention such as tax planning (tax planning), tax avoidance (tax avoidance) and tax evasion (tax evasion). One of the industries that is currently developing rapidly in Indonesia is the business sector of logistics and transportation services. This is indicated by the market data of the Company Size in the transportation and logistics business in 2012 to 2016 which continued to increase with an average growth of $13.7 \%$. Besides the logistics sector, the transportation sector also experienced a fairly high growth. In Bisnis.com's records, since 2015 the transportation \& warehousing sector has accelerated with the contribution to gross domestic product (GDP) experiencing a consecutive increase in the last two years. In 2017, the contribution of transportation \& warehousing reached $5.41 \%$ while in 2016 and 2015 respectively $5.20 \%$ and $5.02 \%$. With the increase in growth, there is a considerable potential for income tax from the logistics and transportation services industry. This condition motivates the management of the company to carry out tax management, so that tax costs become smaller but do not violate applicable tax regulations (tax avoidance).

So far the transportation and logistics companies have been burdened by burdensome tax problems. Transportation and logistics companies have been subject to Article 23 Income Tax (PPh) and Value Added Tax (PPN) deductions, but for the convenience of transportation and logistics companies, according to APTRINDO (Indonesian Truck Entrepreneurs Association) this business tax administration must be simplified. And special tax applies to him. APTRINDO encourages the formulation of special taxes for freight and logistics businesses. Tax is a source of income for the country, while for companies tax is a burden that will reduce net income where large net income is the main goal for all companies, including those engaged in logistics and transportation services. Efforts to minimize taxes that do not violate tax regulations are tax avoidance measures. This is legal because of the lack of imperfections in tax regulations [1]. One of the factors suspected of influencing tax avoidance is the application of corporate governance mechanisms. Good 
companies generally have good corporate governance too, with good governance it is expected that companies can make the right decisions including tax-related decisions. The relationship between tax and corporate governance has been studied by several researchers, including research conducted by [2]. According to him, the relationship between incentive compensation and tax avoidance actions is negative. This negative relationship is more common in companies that have a low level of corporate governance, which in its management the opportunist nature of managers is thought to be the dominant factor. According to Suyanto and Supramono [3] a company's liquidity is predicted to affect the level of corporate tax aggressiveness. Where if a company has a high level of liquidity, it can be described that the company's cash flow is running well. With the existence of a good cash turnover, the company is not reluctant to pay all its obligations including paying taxes in accordance with the rules or applicable law.

\section{Literature Review Framework and Hypothesis Literature Review Agency Theory}

The agency theory view is that there is a separation between the principal and the agent that causes the emergence of potential conflicts that can affect the company's performance. The principal in this agency theory is the shareholders or owners who provide facilities and funds for the company's operational needs while the agent is management who has the obligation to manage the company as mandated by the principal to him [4]. Agung and Wijayanti [5] explained that agency theory is a contractual work relationship between principal and agent, wherein the principal relationship as the owner and investor is tasked with changing and acting according to the principal's wishes.

\section{Good Corporate Governance}

Corporate governance is a system that regulates relations between the board of commissioners, directors, and management in order to create a balance in the management of the company [6].

\section{Good Corporate Governance Mechanism}

The mechanism of Good Corporate Governance in this research is proxied by 3 things, namely ownership structure, independent commissioners, and audit committee.

\section{Ownership Structure}

According to Haryono [7] ownership structure is the proportion between managerial (inside) ownership and institutional ownership (outside). According to Soesetio [8] institutional ownership is the ownership of shares by other companies or institutions (insurance companies, investment companies, asset management and ownership of other institutions). Managerial ownership is measured based on the shares held by management compared to the total outstanding shares. Institutional ownership is measured by the shares owned by the institution compared to the total shares outstanding.

\section{Board of Directors Size}

According to Destriana and Arifin [9] the board of directors is one component in corporate governance (corporate governance) which consists of several members to determine policy and decision making within the company.

\section{Board of Commissioners}

According to FCGI 2001 the board of commissioners in GCG aims to oversee management performance so that the board of commissioners must not involve themselves in management tasks and may not represent the company in third party transactions.

\section{Audit Committee}

According to the revised regulation number IX.I.5 Bapepam LK [11], the audit committee is a committee formed and by and responsible to the Board of Commissioners in order to help carry out the duties and functions of the Board of Commissioners. There are at least 3 audit committees. In addition, one of the audit committee members must have accounting and / or financial background and abilities.

\section{Liquidity}

Liquidity ratio is the ratio needed in analyzing the company's financial statements because the Liquidity ratio is a ratio that shows the company's ability to meet short-term obligations that must be immediately fulfilled by the company [4]. Munawir [12] defines Liquidity as showing the ability of a company to fulfill financial obligations that must be fulfilled immediately, or the ability of a company to fulfill its financial obligations when billed. Obligations that must be met immediately are short-term debt, therefore this ratio can be used to measure the level of security of short-term creditors, and measure whether the company's operations will not be disturbed if these short-term obligations are immediately billed.

\section{Company Size}

Company size can be associated with flexibility in funding. Small-scale companies will find difficulties that include companies that will need more transaction costs to connect with lenders (creditors). Based on research conducted by Cassar and Holmes [13], firm size can be proxied by the logarithmic value of the company's total assets. Firm Firm Size can be measured by the logarithm of the total assets [11]. In this study the size of the company is proxied by the value of the natural logarithm of total assets. The logarithm of total assets is used as an indicator of company size because if 
the size of the company is greater, the fixed assets needed will also be greater [14].

\section{Tax evasion}

The efforts of company management to obtain the expected return through the application of tax management is one of them is through tax avoidance. Rego [15] describes tax avoidance as a method of tax planning to legally reduce the income tax paid. According to, Lumbantoruan [16] tax planning is a structuring action that is related to the consequences of potential tax, the pressure to control every transaction that has tax consequences. However, Desai and Dharmapala [2] see tax avoidance as an abuse of tax shelters.

\section{Framework}

Based on thinking, you can create a research framework as follows:

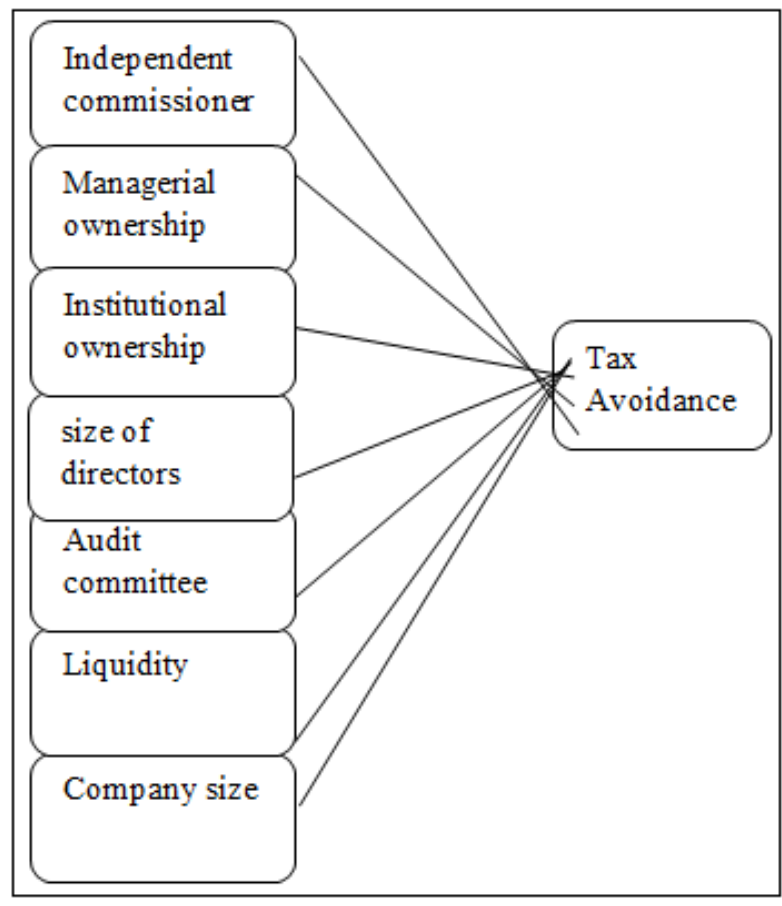

\section{HYPOTHESIS}

Based on the framework that has been made, in order to answer the problem of this research, the proposed Hypothesis is as follows:

$\mathrm{H}_{1}$ : Independent Commissioners have an effect on Tax Avoidance

$\mathrm{H}_{1}$ : Managerial Ownership has an effect on Tax Avoidance

$\mathrm{H}_{1}$ : Institutional Ownership Affects Tax Avoidance

$\mathrm{H}_{1}$ : The size of the Board of Directors influences Tax Avoidance

$\mathrm{H}_{1}$ : The Audit Committee influences Tax Avoidance

$\mathrm{H}_{2}$ : Liquidity affects Tax Avoidance

$\mathrm{H}_{3}$ : Company size has a significant influence on tax avoidance

\section{Research design}

The research approach used in the research is a quantitative research approach. Quantitative research is said because this study aims to provide empirical evidence regarding the effect of corporate governance, liquidity and company size mechanisms on Tax Avoidance. This study uses secondary data, namely data in the form of annual financial documents / logistic companies / transportation documents listed on the Stock Exchange for the period 2012-2017 which are written data relating to the object of research published by the company and IDX. The population used in this study are all companies included in the transportation and logistics sectors listed on the Indonesia Stock Exchange for five years, namely 2012 - 2017. The selection of samples using purposive sampling method with non-probability sampling technique that is the technique of determining samples based on certain criteria . So that the number of samples obtained is as many as 18 logistics and transportation companies listed on the IDX for the period 2012-2017. The method used in this study is to use multiple linear regression models with the help of SPSS version 20.00.

\section{RESEARCH RESULTS}

Effect of corporate governance mechanisms on tax avoidance. Measures of corporate governance mechanisms consisting of independent commissioners, managerial ownership, institutional ownership, size of directors and audit committees indicate that independent commissioners, managerial ownership, and the size of directors have no significant effect on tax avoidance. However, institutional ownership and audit committees show a significant effect on tax avoidance. The following is a discussion of the influence of each corporate governance mechanism on tax avoidance:

Effect of Independent commissioners on tax avoidance. The results showed that independent commissioners did not have a significant effect on tax avoidance. These results indicate that independent commissioners are not effective in supervising the management of the company and cannot influence policies for tax avoidance. Independent board of commissioners is a part that comes from outside management so that independent board of commissioners tend not to be influenced by management actions, they tend to encourage company management to disclose wider information to shareholders and stakeholders. This result is consistent with the findings of Fadhila, et al. [16] That independent commissioners do not have a significant effect on tax avoidance. In line with the research conducted by Annisa and Kurniasih [17] that there is no significant influence on the composition of independent commissioners on tax avoidance. But this result is not in accordance with the results of research conducted by Diantari and Ulupui [18] that the proportion of independent commissioners has a negative effect on tax avoidance. The results of this study are also not in 
accordance with agency theory which explains that the more independent commissioners in the board of commissioners, the better the board of commissioners in overseeing the company. The premise of agency theory, that the board of commissioners requires independent commissioners to oversee and control the actions of directors, is possible for opportunistic behavior to occur [19]. The more the existence of independent commissioners, the supervision of management will be increasingly stringent. Increasingly tight supervision will have an impact on management in carrying out its duties to be more careful and transparent in managing the company so as to minimize tax avoidance practices [18].

Effect of managerial ownership on tax avoidance. Managerial ownership proved to have no effect on tax avoidance. This indicates that managerial parties do not have substantial rights in corporate decision making, so that managerial parties do not have the opportunity and great authority in the company. It can be interpreted that the presence of managerial ownership does not mean that the practice of tax avoidance will decrease. This result is in accordance with the research conducted by Prasetyo and Scouts [20] that managerial ownership does not have a significant effect on tax avoidance. In line with the research conducted by Hidayah [21] that managerial ownership does not affect the practice of tax avoidance. But this result is inversely proportional to the research conducted by Pramudita and Sari [20] which states that an increase in managerial ownership will make the company's tendency to do tax avoidance lower, on the contrary the lower managerial ownership, the higher the tendency of companies to do tax avoidance. This result is not in line with the agency theory which states that differences in interests between managers and principals cause problems that are called agency problems. To overcome this agency problem can be done by increasing managerial ownership in the company. Share ownership by managers will encourage the unification of interests between principals and agents so as to encourage managers to act in accordance with the wishes of the principal so that it can improve company performance. Jensen \& Mecking [19] states that share ownership by managers is seen to be able to harmonize the potential differences in interests between shareholders outside of management so that agency problems can be lost if a manager is also a shareholder.

Effect of institutional ownership on tax avoidance. Institutional ownership proved to have an influence on tax avoidance. These results indicate that the presence of institutional ownership in a company plays an important role in monitoring, disciplining and influencing managers. The greater the institutional ownership, the stronger the control carried out by external parties to the company, which will reduce the occurrence of tax avoidance practices. The relationship of agency theory with this research is the practice of tax avoidance carried out by the company if it is not in good management, there will be a conflict of interest that begins with the existence of information asymmetry. Jensen and Meckeling 1976 in Sri Arthini [22] state that institutional ownership is one of the structures of good corporate governance having a very important role in minimizing agency conflicts that occur between managers and shareholders. Institutional ownership has an important meaning in monitoring management because the presence of ownership by the institution will encourage an increase in more optimal supervision. Institutional ownership is the proportion of share ownership by the company's founding institution, not the institution of public shareholders as measured by the percentage of shares held by internal institutional investors [23]. Companies that have high institutional ownership will be more aggressive in minimizing tax reporting. So that the increasing practice of tax avoidance by companies as the basis of the company to minimize the tax burden. This result is in line with the findings of Alviyani [26] which states that institutional ownership has a significant effect on tax avoidance. The same results were also found by Puspita and Harto [24] and Feranika [25] which state that institutional ownership influences corporate tax avoidance activities. However, this result is contrary to the results of research conducted by Diantari and Ulupui [18] that the proportion of institutional ownership does not affect tax avoidance. The proportion of institutional ownership that does not significantly influence tax avoidance means that the size of the proportion of institutional ownership does not prevent the practice of tax avoidance by the company.

Effect of the size of the board of directors on tax avoidance. The size of directors does not have a significant effect on tax avoidance. These results indicate that the proportion of the board of directors in a company does not affect the practice of tax avoidance at the company. This result is in accordance with the results of Khoirunnisa's study [26] that the board of directors does not have an influence on tax avoidance. But this result contradicts the opinion of Irawan and Farahmita [28] who argue that the board of directors can influence the practice of corporate tax avoidance, the greater the total members in the board of directors, the level of competency that occurs between directors will increase so that expectations of corporate governance will become more well. This result is also not in accordance with the results of research conducted by Putri and Chariri [21] that the board of directors has a significant influence on tax avoidance. This research contradicts the agency theory which states that to reduce the potential for conflict of interest between the parties concerned, good corportae governance is needed. The greater the total members on the board of directors, the level of competition that occurs between directors will increase so that expectations arise that corporate governance will be better. The board of directors is considered to reduce the rate of Tax 
Avoidance due to the better supervision carried out by the board of directors, the possibility of fraud committed by the management will be even smaller.

Effect of audit committee on tax avoidance. The audit committee proved to have an effect on Tax Avoidance. These results indicate that the higher the presence of audit committees in companies will improve the quality of good corporate governance, so that it will minimize the possibility of tax avoidance activities. The audit committee that is in charge of supervising the preparation of the company's financial statements can prevent fraudulent management. Companies that have audit committees will be more responsible and open in presenting financial statements because the audit committee will monitor all activities that take place within the company. Based on agency theory, the higher the existence of an audit committee in the company, the better supervision of company activities and agency conflicts that occur due to management's desire to avoid taxation can be minimized. This shows that companies that have audit committees will be more responsible and open in presenting financial reports because the audit committee will always oversee all activities within the company [29]. Related research conducted by Winata [30] states that the number of audit committees significantly influences tax avoidance by showing that the more audit committees in a company can minimize the practice of tax avoidance by companies. The same results were also found by Diantari and Ulupui [18] that audit committees influence tax avoidance. However, these results contradict the results of a study conducted by Alviyani [26] that the audit committee had no significant effect on tax avoidance by the company.

The effect of liquidity on tax avoidance, in this study liquidity proved to have no effect on tax avoidance. This can be caused by the level of liquidity in the company is relatively the same and the company is very maintaining the level of liquidity at a certain level so that no effect of liquidity on tax avoidance is found. This result is in line with the results of the study of Badriyah [31] that liquidity does not have a significant effect on tax avoidance. Furthermore, research conducted by Fatmawati [32] also cannot prove that liquidity has a significant effect on ETR.

Effect of company size on tax avoidance. Firm size proved to have no significant effect on tax avoidance. These results indicate that the size of the company does not affect the company in practicing tax avoidance. This is because companies may be wrong in recognizing assets so that the actual value of assets can be larger or smaller and is possible because the company does not use the power it has to carry out tax planning because of the limitations in the form of possible spotlight and targets of regulator decisions. This research is in accordance with Prakosa's [27] study which states that company size does not have a significant effect on tax avoidance. But the results of this study are not in accordance with the results of a study conducted by Utomo [13] that Company Size has a significant effect on the practice of tax avoidance, companies with a large size will tend to do tax avoidance practices to maintain the value of net income.

\section{CONCLUSIONS AND RECOMMENDATIONS Conclusion}

Based on the results of testing and discussion that the author has done then conclusions can be drawn as follows:

- The Independent Commissioner has no effect on tax avoidance, because the Independent Commissioner is considered outside of management so that it cannot influence the policy for tax avoidance.

- Managerial ownership does not affect tax avoidance, because managerial parties do not have a large authority to conduct tax avoidance.

- Institutional Commissioners influence tax evasion. The greater the institutional ownership, the stronger the control that external parties do to the company.

- The size of the Board of Directors does not affect tax avoidance due to limited authority.

- The Audit Committee influences tax avoidance because the audit committee will monitor all activities that take place within the company.

- Liquidity has no effect on tax avoidance because the company is very careful.

- Company size does not affect tax avoidance due to the absence of tax planning.

\section{RECOMMENDATION}

Based on the results of the discussion and conclusions above, the authors provide suggestions as follows:

- Independent Commissioner has no effect on tax evasion, as independent commissioners are considered outside management so as not to affect the policy of committing tax evasion

- Management concern to the factors of share ownership by the institution because institutional ownership in a company plays an important role in monitoring, discipline and influencing managers, related to corporate policies including In tax evasion practices that may harm the company.

- The Big companies are expected to be able to make a good tax planning and the company can manage its assets well. 


\section{Pictures and Tabel}

Table-1: Companies Used as Research Samples

\begin{tabular}{|c|l|c|}
\hline No & \multicolumn{1}{|c|}{ Nama Perusahaan } & Kode \\
\hline 1 & Adi Sarana Armada Tbk & ASSA \\
\hline 2 & $\begin{array}{l}\text { Arpeni Pratama Ocean Line } \\
\text { Tbk }\end{array}$ & APOL \\
\hline 3 & Buana Listya Tama Tbk & BULL \\
\hline 4 & Berlian Laju Tanker Tbk & BLTA \\
\hline & $\begin{array}{l}\text { Garuda Indonesia (Persero) } \\
\text { Tbk }\end{array}$ & GIAA \\
\hline 6 & $\begin{array}{l}\text { Humpuss Intermoda } \\
\text { Transportasi Tbk }\end{array}$ & HITS \\
\hline 7 & $\begin{array}{l}\text { Indonesia Transport \& } \\
\text { Infrastructure Tbk }\end{array}$ & IATA \\
\hline 8 & Tanah Laut Tbk & INDX \\
\hline 9 & $\begin{array}{l}\text { Mitrabahtera Segara Sejati } \\
\text { Tbk }\end{array}$ & MBSS \\
\hline 10 & Rig Tenders Tbk & RIGS \\
\hline 11 & Steady Safe Tbk & SAFE \\
\hline 12 & Samudera Indonesia Tbk & SMDR \\
\hline 13 & Sidomulyo Selaras Tbk & SDMU \\
\hline & $\begin{array}{l}\text { Pelayaran Tempuran Emas } \\
\text { Tbk }\end{array}$ & TMAS \\
\hline 14 & Trada Maritime Tbk & TRAM \\
\hline 16 & $\begin{array}{l}\text { PT WEHA Transportasi } \\
\text { Indonesia Tbk }\end{array}$ \\
\hline 17 & Zebra Nusantara Tbk & WEHA \\
\hline 18 & $\begin{array}{l}\text { Wintermar Offshore Marine } \\
\text { Tbk }\end{array}$ & \\
\hline & & WINS \\
\hline
\end{tabular}

Table-2: Descriptive statistics

\begin{tabular}{|l|l|l|l|l|}
\hline Variabel & Minimum & Maximum & Mean & Std. Deviation \\
\hline KOMIND (\%) & 25,00 & 66,67 & 40,8407 & 10,69272 \\
\hline KEPMAN (\%) & 0,00 & 0,22 & 0,0253 & 0,05180 \\
\hline KEPINS (\%) & 14 & 89 & 0,6850 & 0,19172 \\
\hline UKDIR (orang) & 2,00 & 8,00 & 4,3623 & 1,85481 \\
\hline KOMITE (orang) & 3,00 & 4,00 & 3,0290 & 0,16899 \\
\hline CR (rasio) & 0,00 & 6,01 & 0,9059 & 0,91463 \\
\hline SIZE (rasio) & 9,12 & 17,77 & 14,0318 & 2,00183 \\
\hline ETR (rasio) & $-0,58$ & 0,55 & 0,0898 & 0,20947 \\
\hline
\end{tabular}

(Source: Processed Secondary Data, 2019)

Table-3: Multicollinearity Test Results

\begin{tabular}{|l|c|c|}
\hline Variabel & Tolerance & VIF \\
\hline KOMIND & 0,542 & 1,845 \\
\hline KEPMAN & 0,756 & 1,322 \\
\hline KEPINS & 0,518 & 1,929 \\
\hline UKDIR & 0,364 & 2,746 \\
\hline KOMITE & 0,934 & 1,071 \\
\hline CR & 0,756 & 1,322 \\
\hline SIZE & 0,357 & 2,799 \\
\hline
\end{tabular}

(Source: Processed Secondary Data, 2019)
Table-4: Multiple Regression Analysis Test Results

\begin{tabular}{|l|c|c|c|}
\hline \multicolumn{1}{|c|}{ Variabel } & Beta & t hitung & Sig. \\
\hline (Constant) & $-0,997$ & & \\
\hline KOMIND & 0,004 & 1,546 & 0,127 \\
\hline KEPMAN & 0,615 & 1,233 & 0,222 \\
\hline KEPINS & $-0,311$ & $-1,908$ & 0,049 \\
\hline UKDIR & 0,037 & 1,838 & 0,071 \\
\hline KOMITE & 0,421 & 3,057 & 0,003 \\
\hline CR & $-0,020$ & $-0,699$ & 0,487 \\
\hline SIZE & $-0,022$ & $-1,189$ & 0,239 \\
\hline
\end{tabular}

(Source: Processed Secondary Data, 2019) 
Table-5: Statistical T Test Results

\begin{tabular}{|l|r|r|}
\hline Variabel & \multicolumn{1}{c|}{ T } & Sig. \\
\hline KOMIND & 1,546 & 0,127 \\
\hline KEPMAN & 1,233 & 0,222 \\
\hline KEPINS & $-1,908$ & 0,049 \\
\hline UKDIR & 1,838 & 0,071 \\
\hline KOMITE & 3,057 & 0,003 \\
\hline CR & $-0,699$ & 0,487 \\
\hline SIZE & $-1,189$ & 0,239 \\
\hline
\end{tabular}

(Source: Processed Secondary Data, 2019)

\section{REFERENCES}

1. Waluyo.(2013). Indonesian taxation. Jakarta: Salemba Empat.

2. Desai, M. A., \& Dharmapala, D. (2006). Corporate tax avoidance and high-powered incentives. Journal of Financial Economics, 79(1), 145-179.

3. Kusumawati, W. T., \& Hardiningsih, P. (2016). The Effect of Institutional Ownership and Corporate Social Responsibility to the Tax Aggressiveness. In Proceedings International Conference of Banking, Management, and Economics (ICOBAME) Journal.

4. Endriati, Enny., Hidayati, Nur., \& Junaidi. (2013). The Effect of Tax Planning on Profit Management in Non-Manufacturing Companies Listed on the Indonesia Stock Exchange. Jurnal Universitas Islam Malang.

5. Agung, S.R. Ery Wibowo., Wijayanti, Ariska. (2016). Analysis of the Effect of Auditors' Perceptions About the Acceptance of Ethics and the Code of Ethics of the Indonesian Accountants Association on Earnings Management Practices. Stie Journal Semarang, 8(2).

6. Sastriana, D.F. (2013). The Effect of Corporate Governance and Firm Size on Companies experiencing (Financial Distress). Diponegoro Journal of Accounting, 3, 1-10.

7. Haryono, Jusup. (2005). Accounting Basics. Issue 6. Yogyakarta: Penerbit Sekolah Tinggi Ilmu Ekonomi YKPN.

8. Al-Najjar, B., \& Taylor, P. (2008). The relationship between capital structure and ownership structure: New evidence from Jordanian panel data. Managerial Finance, 34(12), 919-933.

9. Destriana, M., Dan Arifin, L.(2016) Effect of Firm Size Corporate Governance and Corporate Characteristics on Earnings Management. Journal of Business and Accounting, 18, 84-93.

10. Abor, J., Dan Biekpe, N. (2009). How Do We Explain The Capital Structure of Smes in subSaharan Africa: Evidence from Ghana. Journal of Economic Studies, 36(1), 83-97.

11. Munawir, S. (2010). Analysis of the fourth edition of the financial statements. Fifth Printing. Yogyakarta: Liberty.

12. Cassar, G., dan Holmes, S. (2003). Capital Structure and Financing of Smes: Australian
Evidence. Journal of Accounting and Finance, 43, 123-147.

13. Atiqoh, Z. (2016). The Influence of Financial Performance, Company Size, Sales Growth, and Share Ownership on Capital Structure. Journal of Science and Accounting Research, 5(5).

14. Rego, S. (2003). Tax-Avoidance activities of U.S. multinational Corporations. Contemporary Accounting Research, 20, 805-833.

15. Lumbantoruan, Sophar. (2008). Tax Accounting. Jakarta: Grasindo.

16. Fadhilah, Rahmi. (2017). The Effect of Good Corporate Governance on Tax Avoidance. Jurnal Universitas Negeri Padang.

17. Annisa, N. A., \& Kurniasih, L. (2012). Pengaruh corporate governance terhadap Tax avoidance. Jurnal Akuntansi \& Auditing, 8(2), 95189.

18. Sunarsih, U., \& Oktaviani, K. (2016). Good Corporate Governance In Manufacturing Companies Tax Avoidance. Etikonomi, 15(2).

19. Jensen, M. C., \& Meckling, W. H. (1976). Theory of the firm: Managerial behavior, agency costs and ownership structure. Journal of financial economics, 3(4), 305-360.

20. Prasetyo, E., \& Pramuka, B.A. (2018). Effects of Institutional Ownership, Managerial Ownership, and Proportion of Independent Board of Commissioners on Tax Avoidance. Journal of Economics, Business and Accounting (JEBA), 20(2), 1-15.

21. Lee, H. C., Liu, W. W., Chai, S. P., Mohamed, A. R., Aziz, A., Khe, C. S., ... \& Hashim, U. (2017). Review of the synthesis, transfer, characterization and growth mechanisms of single and multilayer graphene. RSC Advances, 7(26), 15644-15693.

22. Khoirunnsia. (2015). The effect of corporate governance on tax avoidance on manufacturing companies listed on the Indonesia Stock Exchange. Jurnal Universitas Lampung, Bandar Lampung, Indonesia.

23. Fritz, H. M., Kongko, W., Moore, A., McAdoo, B., Goff, J., Harbitz, C., \& Titov, V. (2007). Extreme runup from the 17 July 2006 Java tsunami. Geophysical Research Letters, 34(12).

24. Puspita, S. R., \& HARTO, P. (2014). Pengaruh tata kelola perusahaan terhadap penghindaran pajak (Studi terhadap Perusahaan Non-Keuangan yang Terdaftar di Bursa Efek Indonesia Tahun 2010-2012) (Doctoral dissertation, Fakultas Ekonomika dan Bisnis).

25. Feranika, A. (2016). Pengaruh Kepemilikan Institusional, Dewan Komisaris Independen, Kualitas Audit, Komite Audit, Karakter Eksekutif, Dan Leverage Terhadap Tax Avoidance (Studi Empiris Pada Perusahaan Manufaktur di Bursa Efek Indonesia dengan Tahun Pengamatan 20102014). Jurnal Akuntansi \& Keuangan Unja, 1(4).

26. Alviyani, K. (2016). The Effect of Corporate Governance, Executive Character, Company Size, 
and Leverage Against Tax Avoidance .JOM Fekon, $3(1)$.

27. Prakosa, K.B. (2014). The Effect of Profitability, Family Ownership and Corporate Governance on Tax Avoidance in Indonesia. SNA 17 Mataram, 2427 September.

28. Irawan, H. P., \& Farahmita, A. (2012). Pengaruh kompensasi manajemen dan corporate governance terhadap manajemen pajak perusahaan. Skripsi, Depok: Universitas Indonesia.

29. Putri, R. A. H., \& Chariri, A. (2017). Pengaruh Financial Distress Dan Good Corporate Governance Terhadap Praktik Tax Avoidance Pada Perusahaan M Anufaktur. Diponegoro Journal of Accounting, 6(2), 56-66.
30. Mia, L., \& Winata, L. (2014). Manufacturing strategy and organisational performance: The role of competition and MAS information. Journal of Accounting \& Organizational Change, 10(1), 83115.

31. Badriyah, T., Wijayanto, E. T., Syarif, I., \& Kristalina, P. (2017, August). A hybrid recommendation system for E-commerce based on product description and user profile. In 2017 Seventh International Conference on Innovative Computing Technology (INTECH) 95-100). IEEE.

32. Hidayati, M. D., Ersam, T., Shimizu, K., \& Fatmawati, S. (2017). Antioxidant activity of Syzygium polyanthum extracts. Indonesian Journal of Chemistry, 17(1), 49-53. 